\title{
KONSEP ORWELISASI DAN PARKINSONISASI DALAM SISTEM PEMERINTAHAN PUBLIK
}

\author{
Yeni Sri Lestari \\ Fakultas Ilmu Sosial dan Ilmu Politik Universitas Teuku umar \\ email: yenilestari24@yahoo.com
}

\begin{abstract}
This article discusses the importance of the role of the right government system within a country. One of the determinants of the good governance system is based on the accuracy in the selection of government bureaucracy system. Therefore, to provide a more detailed understanding, this article will discuss about the bureaucratic system. This review will examine two bureaucratic systems currently dominantly applied by most countries in the world, namely Orwell Bureaucracy (Orwellization) and Parkinson's Bureaucracy (Parkinsonization). This article is divided into four studies, first on the backgrounds of Orwell and Parkinson, the two studies on the concept of Orwellization and Parkinsonization framework, the three analyzing the application of both concepts within a country, and the fourth is criticism given by experts to the concept of Orwellization and Parkinsonization. In this study it is found that the concept of Orwellization and Parkinsonization is still relevant in studying the problems of bureaucratic systems in some countries, the concept of Orwellisasi can create a strong state but weaken the issue of Human Rights (HAM), while the concept of Parkinsonization contributed considerably in the development effort but weaken the system of recruitment of public officials. However, there are some experts who give criticism to the concept of bureaucracy Orwellisasi and Parkinsonisasi this, this is not apart from weakness owned by each bureaucracy concept.
\end{abstract}

Keywords: bureaucracy, Orwellisasi, dan Parkinsonisasi 


\section{PENDAHULUAN}

Negara sebagai sebuah organisasi utama dalam masyarakat menjalankan pelbagai fungsinya. Dikatakan sebagai organisasi karena negara memiliki struktur dan fungsi untuk menjalankan tugasnya, terutama untuk mencapai kebaikan bersama yaitu kebaikan bagi warga negaranya. Etzioni (1964) mengartikan organisasi sebagai suatu unit sosial yang sengaja dibentuk (pengelompokkan manusia) dan dibentuk kembali untuk mencapai tujuan-tujuan tertentu.

Keberhasilan sebuah organsasi tidak terlepas dari konsep yang terkandung dalam organisasi itu sendiri yang kemudian akan mempengaruhi jalannya sebuah konsep organisasi yang bertujuan untuk menciptakan pemerintahan yang baik. Salah satu konsep organisasi yang sangat berpengaruh dalam proses pemerintahan ialah konsep birokrasi.

Konsep birokrasi pertama kali dikenal pada abad ke-18 di Eropa Barat, berasal dari kata Bureau yang merujuk kepada badan yaitu sebuah tempat bekerja bagi pegawai negara. Secara ringkas, birokrasi dapat diartikan sebagai organisasi terstruktur yang memiliki prosedur untuk melaksanakan sistem pemerintahan dan kewenangan hukum sah yang digunakan untuk mencapai tujuan-tujuan dari organisasi tersebut, dalam hal ini ialah tujuan sebuah negara.

Berbicara mengenai birokrasi akan selalu berkaitan dengan segala bidang kehidupan bermasyarakat. Masyarakat sebagai sistem sosial sudah tentu terdiri dari pelbagai struktur sosial baik dalam bidang politik atau ekonomi, dalam bentuk organisasi besar maupun kecil, ataupun yang termasuk dalam lingkup pemerintahan bahkan swasta.

Birokrasi menjadi salah satu asas utama untuk mengatur dan mengontrol sistem sosial masyarakat, suka atau tidak suka masyarakat pada hakikatnya tidak dapat melepaskan diri dari sistem birokrasi sebuah negara. Bagi negara demokrasi, kehadiran partai politik dalam sistem birokrasi negara merupakan hal yang mutlak terjadi.

Kehadiran partai politik dalam sistem birokrasi memberikan pengaruh yang cukup signifikan terhadap model birokrasi sebuah negara, hal ini dikarenakan partai politik memiliki ideologi yang berbeda antar satu dengan lainnya. Hal tersebut, seringkali menimbulkan permasalahan tersendiri bagi sistem birokrasi sebuah negara, seperti partai pemerintah yang berkuasa dipastikan akan menguasai hampir semua jabatan-jabatan yang strategis dalam lembaga-lembaga negara.

\section{Kajian Literatur}

Kajian Literatur mengenai konsep birokrasi Orwell dan Parkson masih sangat sedikit ditemukan, hal ini disebabkan munculnya kajian yang lebih modern pada sistem birokrasi global sehingga memfokuskan kepada sistem reformasi birokrasi. Namun begitu, perbandingan kajian mengenai sistem birorkasi Orwell dan Parkson tidak dapat ditinggalkan begitu saja, dikarenakan kedua-dua konsep birokrasi tersebut telah banyak diaplikasikan dalam sistem birokrasi sebuah negara bahkan mengantarkan sebuah negara menjadi negara dengan birokrasi yang mapan, hal ini tidak terlepas dari peran penting kedua-dua konsep birokrasi tersebut.

Karya-karya Orwell dapat dilihat dari pelbagai novel yang ia tulis. Di dalam karyanya, Orwell banyak menyinggung mengenai bagaimana sistem birokrasi yang ideal menurutnya, seperti Down and Out in Paris and London (1933), Burmese Days (1934), A Clergyman's Daughter (1935), Keep the Aspidistra Flying (1936), The Road to Wigan Pier (1937), dan Coming Up for Air (1939). Selain itu, Animal Farm dan Nineteen Eighty-Four. Animal Farm merupakan karya Orwell yang banyak menginspirasi publik mengenai kehidupan pada masa revolusi di bawah pemerintahan Stalin, sedangkan Nineteen Eighty-Four menceritakan ramalan Orwell terhadap sistem totalitarianisme.

Kajian mengenai birokrasi Parkinson dapat dilihat dari karya Parkinson yang berjudul Parkinson's Law yang diterbitkan pada tahun 1957. Dalam tulisannya tersebut, Parkinson dengan sangat jelas berusaha menjelaskan mengenai pertambahan jumlah pegawai publik dalam 
sebuah sistem administrasi negara tidak berkaitan dengan bertambahnya jumlah beban kerja. Karya ini juga memberikan sumbangan yang besar bagi sistem birokrasi pada masa tersebut, khususnya di wilayah Asia.

\section{METODE PENELITIAN}

Kajian ini menggunakan metode analisis kualitatif, yakni memberikan deskripsi mengenai persoalan kajian yang dikaitkan dengan konsep-konsep yang digunakan untuk membahas persoalan tersebut. Data yang didapatkan dalam penelitian ini merupakan data sekunder yang didapatkan melalui kajian literatur yang berkaitan dengan persoalan kajian. Data yang didapatkan kemudian dianalisis dan dikaji kembali sesuai dengan kebutuhan untuk menjawab persoalan kajian dengan memberikan penjelasan melalui penggambaran kata-kata (description).

\section{HASIL DAN PEMBAHASAN}

\section{a. Latar Belakang Orwell dan Parkinson}

George Orwell atau yang memiliki nama asli sebagai Eric Arthur Blair (25 Juni 1903-21 Januari 1950) merupakan seorang penulis novel, esei, wartawan, dan pengamat politik serta budaya di Inggirs. Blair mulai ramai dikenal oleh khalayak ramai, ketika tulisan-tulisannya dalam bentuk buku, esei maupun novel memberikan motivasi bagi perubahan sistem penindasan manusia saat itu.

Lahir di Motihari-Bihar, India pada era penjajahan Inggris, Blair yang saat itu berumur 1 tahun dibawa oleh sang ibu kembali ke Inggris. Di Inggris Blair mulai memasuki jenjang pendidikan di pelbagai sekolah dan perguruan tinggi. Blair pernah mendapatkan King's Scholar di tahun 1917-1921 namun, Blair merasa tidak cocok dengan dunia pendidikan yang baginya tidak memberikan kebebasan seperti yang ia harapkan.

Berhenti dari dunia pendidikan, Blair memutuskan untuk bergabung dengan Police Imperial British dan ditugaskan di wilayah Burma-Myanmar. Aktivitasnya sebagai seorang polisi juga tidak bertahan lama, hal ini dikarenakan dua faktor, pertama cita-cita Blair ialah menjadi seorang penulis dan kedua Blair merasa pekerjaannya sebagai polisi hanya menjadikannya sebagai individu yang mendukung sistem politik yang cenderung menindas kehidupan orang banyak.

Kehidupannya kemudian ia dedikasikan dengan banyak menulis karya-karya yang sebagian besar berasal dari pengalaman hidupnya yang merasakan penindasan dari kekuasaan negaranegara penjajah pada masa itu terhadap negara-negara jajahan. Blair memiliki keinginan untuk dapat melepaskan dan menghentikan pegaruh dari imperialisme negara penjajah yang berbentuk penindasan terhadap manusia dari penguasaan manusia lainnya.

Blair mulai menjadi perhatian banyak orang ketika karya-karyanya yang fenomenal mampu memberikan gambaran yang saat itu paling banyak dirasakan oleh masyarakat. Beberapa karya Blair yang terkenal dan terinspirasi dari pengalaman hidupnya ialah seperti Down and Out in Paris and London (1933), Burmese Days (1934), A Clergyman's Daughter (1935), Keep the Aspidistra Flying (1936), The Road to Wigan Pier (1937), dan Coming Up for Air (1939).

Blair juga menghasilkan dua buah karya esei yang menentukannya sebagai seorang penulis prestisius melalui karyanya yang berjudul Animal Farm dan Nineteen Eighty-Four. Animal Farm secara ringkas mengumpamakan keadaan yang timbul akibat penyelewengan ide-ide sosialis dalam Revolusi Rusia di bawah kepemimpinan Stalin, sedangkan Nineteen Eighty-Four menceritakan mengenai ramalan Blair tentang keadaan dunia saat itu yang berada di bawah rezim totalitarianisme.

Cyril Northcote Parkinson akrab disapa dengan panggilan Parkinson dilahirkan pada 30 juli 1909 di Inggris. Memiliki latar belakang pendidikan yang beragam, ia mulai bersekolah di sekolah St. Peter yang bertempat di York, hingga melanjutkan kuliahnya di Universitas Cambridge dan meraih gelar doktoralnya di King Collage London. 
Parkinson dikenal sebagai pakar yang ahli dalam sejarah kelautan di Inggris, selain itu ia dikenal juga sebagai seorang penulis handal yang telah melahirkan hampir 60 buku. Buku yang paling terkenal dari Parkinson ialah Parkinson's Law yang merupakan kerangka dasar dalam pembentukakan konsep Birokrasi Parkinsonisasi.

Buku Parkinson's Law menjadi penentu titik balik kehidupan Parkinson sebagai seorang sarjana penting dalam bidang manajemen dan pelayanan publik. Parkinson's Law secara ringkas menjelaskan bahwa perkembangan birokrasi tidak dapat dihindari dengan alasan " penambahan kerja sesungguhnya adalah untuk memenuhi waktu luang".

Parkinson juga dikenal luas dalam dedikasinya terhadap dunia pendidikan, ia merupakan seorang pengajar di pelbagai sekolah dan universitas. Selain mendedikasikan waktunya dalam kajian-kajian mengenai tentara laut Inggris, ia tetap aktif menulis dan melahirkan beberapa karya ilmiah yang memberikan sumbangan pengetahuan kepada masyarakat luas seperti The Trade Winds, Trade in the France Wars (1793-1815), British Intervention in Malaya (18671877), dan A Short History of the British Navy (1776-1816).

\section{b. Kerangka Konsep Birokrasi Orwell dan Parkinson}

Konsep Birokrasi Orwell atau dikenal dengan istilah Orwellisasi merujuk kepada apa yang dikatakan oleh seseorang tetapi bukan realita, hal ini sering kita temukan dalam kehidupan sehari-hari terutama dalam ruang sosial, politik bahkan agama. Dalam Orwellisasi, kebenaran yang dipercayai ada oleh seseorang sebenarnya hanya berupa retorika saja, oleh sebab itu, Orwellisasi menganjurkan untuk tidak hanya percaya terhadap sebuah pernyataan akan tetapi harus disertai dengan adanya kebenaran dan praktiknya.

Konsep Orwellisasi sangat menekankan kepada kepentingan kebebasan yang disebut sebagai Public Sphere. Hal ini dikarenakan, dalam gambaran Novel 1948 yang ditulis oleh Orwell menceritakan bagaimana sebuah sistem demokrasi mengontrol setiap kehidupan masyarakat, sehingga Orwellisasi dikenal sebagai alat perpanjangan tangan negara dalam menjalankan kendali terhadap masyarakat luas.

Pemikiran utama mengenai Birokrasi Orwel berasal dari novel yang berjudul Nineteen Eighty Four. Dalam novel ini Orwell mengisahkan latar belakang perang dingin yang terjadi pada masa itu sehingga masyarakat berada di bawah kendali dan manipulasi pemerintah, di mana sistem politik pada masa itu dikenal dengan sebutan English Socialism (IngSoc) yang dikuasai oleh golongan-golongan elit politik.

Individualisme dan kebebasan berfikir pada masa itu dianggap sebagai sebuah tindakan kriminal (Thoughtcrime) yang dikarenakan wujudnya sebuah sistem pemerintahan yang tirani. Hal ini digambarkan dari sosok pemimpin dalam novel tersebut ialah Big Brother yang dikenal dengan sistem pemerintahannya yang menindas, yang ia artikan demi wujudnya kebaikan negara.

Tokoh lainnya dalam Novel 1984 ialah Winston Smith yang digambarkan sebagai seorang pegawai pemerintahan di Ministry of Truth yaitu sebuah lembaga yang bertanggung jawab mengurus propoganda dan manipulasi sejarah yang sedemikian rupa diatur agar selalu pro terhadap pemerintah. Smith secara diam-diam membenci dan melakukan pemberontakan terhadap sistem tersebut yang menurutnya didominasi oleh sistem pemerintahanyang totalitarian.

Akhirnya, Novel 1984 mencita-citakan terjadinya sebuah distopia yaitu keadaan di mana suatu masyarakat yang dikuasasi oleh birokrasi elit partai politik yang menggunakan kekuasaannya untuk menciptakan ketakutan dan berwenang untuk mengawasi, memaksa, dan melukai rakyat. Oleh karena itu, novel ini menceritakan bagaimana sebuah kekuasaan negara bertumpu pada partai pemerintah yang terpusat dan birokrasi digunakan untuk melakukan kontrol kepada semua aspek kehidupan masyarakat. 
Berdasarkan Novel 1984 karya Orwell, Ever H. D kemudian mendefinisikan Birokrasi Orwell sebagai peningkatan kontrol birokratik secara keseluruhan. Kontrol, tekanan, dan paksaan dari birokrasi bertujuan agar proses pembangunan sebuah negara dapat berjalan lancar, hal ini juga menyebabkan semakin kuatnya birokrasi dan menjadi alat kekuasaan negara untuk mengendalikan kegiatan ekonomi, politik, dan sosial masyarakat yang mutlak melalui pengaturan bahkan paksaan.

Birokrasi Orwell dapat disimpulkan sebagai penguasaan atas sebagian besar kehidupan masyarakat yang disebabkan ketergantungan masyarakat kepada birokrasi melalui manifestasi program-program pembangunan yang direncakan oleh pemerintah dan kebanyakan program tersebut bersifat top-down. Oleh karena itu, untuk mengendalikan rasa aman bagi masyarakat dalam sebuah negara ialah melalui kekuasaan state power yang bertujuan untuk memastikan setiap keputusan yang berkaitan dengan program pembangunan masyarakat sudah tepat sasaran.

Parkinson dalam artikelnya yang berjudul "Parkinson's Law and Other Studies in Administration" menjelaskan mengenai peningkatan jumlah pegawai pemerintahan tidak berkaitan dengan faktor lain seperti meningkatnya beban kerja. Peningkatan beban kerja hanya untuk memenuhi waktu luang serta pekerjaan merupakan sebuah tuntutan waktu, sehingga beban kerja tidak berkaitan dengan jumlah pegawai yang diperlukan.

Berkurangnya aktifitas bukan berarti tersedianya waktu luang maupun wujudnya pengangguran, namun beban kerja didasarkan kepada tahapan kepentingan dan kerumitan yang secara langsung berkaitan dengan kadar waktu yang diperlukan untuk menyelesaikan pekerjaan. Tesis yang diajukan oleh Parkonsn ialah sebagai kritik terhadap isu umum yang berkembang, yaitu peningkatan jumlah pegawai pemerintah sebagai cerminan dari meningkatnya beban kerja serta peningkatan jumlah pegawai akan menyebabkan berkurangnya beban kerja dan waktu kerja di kalangan pegawai.

Hukum Parkinson selanjutnya menjelaskan peningkatan jumlah pegawai pemerintahan akan tetap meningkat walaupun beban kerja bertambah, berkurang maupun permanen. Kepentingan Hukum Parkinson terletak pada fakta bahwa hukum berkembang berdasarkan beberapa faktor yang mengendalikan perkembangan itu sendiri.

Faktor yang menyebabkan peningkatan jumlah pegawai dirumuskan oleh Parkinson melalui dua kenyataan, yaitu:

a. Seorang pegawai biasanya ingin menambah bawahan (subordinate), bukan mencari persaingan (rival), dan

b. Pegawai-pegawai tersebut akan bertindak dan bekerjasama satu dengan lainnya.

Faktor pertama dari hukum Parkinson dapat dideskripsikan bahwa pegawai A menganggap dirinya memiliki beban kerja (overworked). Hal ini pada dasarnya merupakan realita maupun bayangan yang terdapat pada diri A yang disebabkan oleh faktor usia, tingkat kejenuhan dan lainnya sehingga untuk mengatasi hal tersebut maka A memiliki tiga pilihan untuk mengatasi persoalan tersebut, yaitu:

1. Berhenti bekerja,

2. Membagikan beban kerja kepada pegawai B yang memiliki kedudukan yang sama dengan pegawai $\mathrm{A}$, dan

3. A melantik 2 orang pembantu $\mathrm{C}$ dan $\mathrm{D}$ yang memiliki kedudukan/jabatan yang lebih rendah dari A.

Secara rasional, dari ketiga pilihan yang terdapat di atas maka A akan lebih cenderung untuk memilih opsi ketiga dengan pertimbangan bahwa opsi pertama akan menyebabkan A mengalami beberapa kerugian seperti kehilangan pengahsilan, bonus maupun uang pensiun. Sedangkan opsi kedua akan menyebabkan munculnya persaingan antara A dan B dalam kenaikan jabatan, sehingga opsi ketiga dengan melantik $\mathrm{C}$ dan $\mathrm{D}$ merupakan pilihan yang paling rasional bagi A untuk meminimalisir ancaman bagi kedudukan yang dimiliki oleh $\mathrm{A}$. 
Pelantikan C dan D secara bersamaan bertujuan untuk mengamankan kedudukan A. Hal ini dikarenakan, apabila A hanya melantik $\mathrm{C}$ saja maka hal tersebut sama saja dengan melantik $\mathrm{B}$, sehingga pelantikan C dan D secara bersamaan akan mengamankan kedudukan A. Selanjutnya, di suatu waktu ketika $\mathrm{C}$ dan $\mathrm{D}$ merasa beban kerja mereka meningkat, maka $\mathrm{C}$ dan $\mathrm{D}$ dapat mengangkat bawahan atas persetujuan A, inilah yang dimaksud dengan Hukum Parkinson yang menyatakan bahwa sebuah organisasi akan terus membesar.

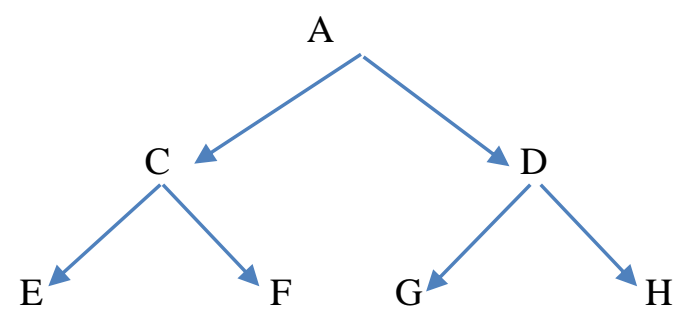

Penjelasan dari faktor pertama akan berkaitan dengan faktor kedua, di mana beban kerja yang seharusnya diselesaikan oleh satu pegawai akan menjadi pekerjaan yang diselesaikan oleh tujuh orang dan tentunya A tetap memiliki peluang terbesar untuk mendapatkan kenaikan jabatan. Pegawai lainnya, C, D, E, F, G, dan H akan menjalankan tugas masing-masing namun kesemuanya akan tetap saling berkoordinasi dan bekerjasama dalam menyelesaikan beban kerja utama A, berdasarkan hal ini juga tidak dapat dipungkiri bahwa satu pekerjaan utama dari A akan terus meningkat/bertambah dari waktu ke waktu.

Hukum Parkinson merupakan hukum yang bersifat saintifis dan tidak dapat digunakan hanya dalam suatu keadaan politik tertentu. Oleh karena itu, Hukum Parkinson hanya mampu untuk menerangkan peningkatan jumlah pegawai publik yang mana hal tersebut terjadi atas dasar peningkatan beban kerja ataupun banyaknya pegawai serta mekanisme pergerakan peningkatan pegawai dalam sebuah organisasi dianggap Parkinson sebagai wujud untuk memperlihatkan kepentingan diri (vested interest).

Besarnya jumlah pegawai dan struktur kerja yang terdapat dalam sebuah organisasi tanpa mempertimbangkan dan memperhitungkan pekerjaan yang akan diselesaikan menyebabkan munculnya disharmonisasi antar pegawai. Selain itu, besarnya jumlah pegawai juga akan turut memperlambat pelyanan publik karena banyaknya prosedur yang harus dilewati sehingga tujuan utama terciptanya birokrasi untuk melancarkan proses penyelesaian pekerjaan akan hilang.

Perubahan dan kemajuan zaman yang berdampak kepada masyarakat luas turut merubah pola pikir masyarakat dalam menuntut pelayanan publik yang lebih sempurna. Oleh karena itu, Parkinson menawarkan sebuah konsep New Public Management yang merupakan konsep pelayanan publik secara langsung, efisien, seksama dan menyenangkan dengan cara melakukan perubahan dalam organisasi maupun pelayanan agar lebih seimbang.

\section{c. Konsep Birokrasi Orwell dan Parkinson dalam Sistem Pemerintahan}

Penerapan konsep birokrasi Orwell dapat dikaji melalui sistem pemerintahan Orde Baru (Orba) di Indonesia. Zaman Orba di Indonesia merupakan zaman pemerintahan yang dipimpin oleh Presiden Soeharto yaitu dari tahun 1966-1998, dimana pada masa awal pemerintahan Soeharto peta politik dan ekonomi Indonesia masih kacau balau disebabkan oleh konflik yang terjadi antara pemerintah Indonesia dengan Partai Komunis Indonesia (PKI).

Penumpasan dan pelarangan PKI pada masa Soeharto memberikan pelajaran tersendiri bagi Soeharto dalam memimpin Indonesia. Segala hal yang dirasa dapat menganggu kestabilan negara dikontrol dengan sangat ketat oleh Soeharto dengan cara memberikan kekuasaan yang besar bagi Angkatan Bersenjata Republik Indonesia (ABRI) dalam urusan kenegaraan, hal ini 
ditandai dengan adanya dwifungsi ABRI, serta merangkul setiap elemen masyarakat yang tergabung dalam Golongan Karya (Golkar) untuk bersama-sama menjalankan pemerintahan.

Imbalan yang diberikan Soeharto kepada loyalis yang setia mendukung pemerintahannyapun berupa kedudukan maupun jabatan dalam setiap struktur pemerintahan mulai dari tingkat pusat hingga ke tingkat desa. Warisan sistem pemerintahan Orde Lama (Orla) banyakmemberi tantangan bagi Soeharto terutama dalam membenahi kestabilan negara. Oleh karena itu, untuk memperlancar usahanya dalam membenahi negara, Soeharto memberikan banyak peluang kepada setiap individu maupun kelompok yang menjadi pendukung setia Soeharto terutama dari kalangan ABRI dan Golkar untuk mendapatkan jabatan di pemerintahan.

Sistem birokrasi di Indonesia pada masa Orba yang didominasi oleh loyalis Soeharto telah menciptakan sebuah institusi baru. Liddle (1985), yang telah melakukan kajian terhadap sistem birokrasi di Indonesia menyatakan bahwa birokrasi masa Orba dicirikan sebagai "New Order Pyramid", yaitu peran presiden yang dominan, peran dan keaktifan tentara dalam politik, proses pengambilan keputusan terpusat pada birokrasi serta hubungan negara dan masyarakat terdiri dari cooptation dan responsiveness with repression.

Kajian Liddle tersebut secara tegas menggambarkan bahwa pusat kekuasaan selalu berakhir kepada keputusan ataupun persetujuan dari presiden. Hal tersebut menjadi lebih dominan manakala tentara dan birokrasi yang bekerja dalam sistem pemerintahan Indonesia merupakan loyalis Soeharto, sehingga kebijakan yang dibuat cenderung mengabaikan kepentingan masyarakat banyak.

Implementasi birokrasi Orwell pada masa Orba sangat terlihat dari besarnya kontrol pemerintah terhadap amsyarakat terutama dalam hal pengambilan keputusan, dimana setiap keputusan yang ditetapkan adalah tepat dan tidak menyalahi hak kebebasan. Hal tersebut terlihat jelas dalam kepemimpinan Soeharto selama 32 tahun, dimana Soeharto sebagai pemilik kuasa dominan cenderung menetapkan kebijakan yang sebenarnya kurang tepat namun dianggap tepatdan dipaksakan sebagai upaya untuk menjaga stabilitas negara, seperti peraturan mengenai kebebasan pers, penetapan mekanisme SIUPP (Surat Izin Usaha Penerbitan Pers), pembatasan kebebasan berserikat (pembatasan partai politik peserta pemilihan umum).

Kebijakan yang dominan tersebut tidak terlepas dari munculnya kewaspadaan terhadap kembalinya kondisi ketidakamanan seperti pada masa kerusuhan dan konflik dengan PKI. Oleh sebab itu, state power dan segala keputusan kenegaraan harus dikontrol secara ketat, bahkan seringkali berujung pada sifat pemerintahan yang otoriter.

Latar belakang kepemimpinan Soeharto yang demikian, tidak terlepas dari upayanya untuk mengendalikan kegiatan ekonomi, politik dan sosial melalui regulasi yang cenderung menggunakan paksaan. Fokus pemerintahan Soeharto ialah berupaya mewujudkan modernisasi melalui stabilitas politik dan pertumbuhan ekonomi sebagai jawaban untuk membawa Indonesia kepada kemapanan, hal ini terlihat jelas dari agenda Soeharto yang sangat antipartai dan program pembangunan Soeharto yang dikenal dengan istilah Repalita (Rencana Pembangunan Lima Tahun).

Sistem pemerintahan Soeharto tersebut dapat berjalan dengan baik apabila Ia mampu mengendalikan, mengontrol bahkan menggunakan tekanan dan paksaan untuk mencapai tujuan agar program pembangunan negara berhasil. Keberhasilan tersebut hanya dapat dicapai apabila Soeharto mampu mengendalikan birokrasi disetiap lini, sehingga upaya yang harus dilakukan oleh Soeharto ialah memastikan bahwa setiap lapisan birokrasi di Indonesia harus mendukung bahkan setia terhadap Soeharto dan segala kebijakannya.

Upaya yang dilakukan Soeharto untuk menguasai dan mengendalikan birokrasi ialah dengan memberikan jabatan-jabatan kenegaraan hingga jabatan daerah kepada ABRI maupun anggota Golkar. ABRI dan Golkar merupakan senjata utama Soeharto untuk menguasai sistem birokrasi di Indonesia dengan menempatkan orang-orang yang memang patuh dan mendukung 
kepemimpinan Soeharto sehingga hampir setiap posisi jabatan struktural selalu diisi oleh ABRI dan Golkar.

Terpeliharanya dominasi kekuasaan Soeharto sampai dengan 32 tahun dilatarbelakangi oleh kepiawaian Soeharto dalam mengelola sistem birokrasi di Indonesia, hal ini meliputi:

1. Penafsiran kubu Soeharto terhadap Pasal 7 Undang-undang Dasar 1945, yang menekankan kepada kalimat "dan sesudahnya dapat dipilih kembali". Hal ini menyebabkan masa pemerintahan Soeharto sangat lama yaitu hingga 7 periode.

2. Pembatasan kepada kebebasan untuk berserikat, baik dalam mendirikan partai politik hingga pendirian organisasi masyarakat maupun profesi. Oleh sebab itu, pada masa Orba hanya dikenal tiga partai besar yaitu Partai Persatuan Pembangunan (PPP), Partai Demokrasi Indonesia (PDI), dan Golkar. Sedangkan keberadaan organsiasi masyarakat dan profesi yang diakui negara ialah yang kesemuanya dikendalikan dan dikontrol ketat oleh rezim Soeharto seperti, Persatuan Wartawan Indonesia (PWI), Komite Nasional Pemuda Indonesia (KNPI), Kamar Dagang Indonesia (KADIN), Korps Pegawai Negeri Republik Indonesia (KORPRI), Majelis Ulama Indonesia (MUI), Persatuan Guru Republik Indonesia (PGRI), dll.

3. Pembatasan kebebasan pers dan pembredelan terhadap media yang memberitakan keburukan dan mengkritik pemerintahan Soeharto.

4. Pelaksanaan pemilu yang tidak demorkatif dan cenderung manipulatif.

5. Keanggotaan Dewan Perwakilan Rakyat (DPR) dan Dewan Perwakilan Rakyat Daerah (DPRD) dari unsur ABRI, serta sebagian anggota Majelis Permusyawaratan Rakyat (MPR) diangkat oleh presiden.

6. Introduksi dan pelembagaan Golkar sebagai "partai pemerintah" yang bertugas memenangkan pemilu manipulatif Orba.

7. ABRI melalui konsep dwifungsi ABRI secara resmi diakui sebagai bagian dari kekuatan sosial politik (Syamsuddin Haris, 2014:3-4).

Berkuasanya rezim Soeharto tidak terlepas dari faktor-faktor yang telah disebutkan diuraikan sebelumnya. Keberhasilan faktor tersebut didorong oleh penempatan orang-orang Soeharto dalam setiap lini kebijakan, sehingga Soeharto dapat mengontrol dan mengendalikan setiap bidang politik, ekonomi dan sosial secara penuh dengan dukungan dan bantuan dari birokrasi yang ada di bawah kekuasaannya.

Sistem birokrasi Indonesia pada masa Soeharto juga dikuasai oleh kerabat dan rekan dari Soeharto melalui sebuah sistem yang dikenal dengan istilah "patrimonialisme", hal ini bertujuan agar pusat kekuasaan berada pada klan Soeharto. Crouch (1979) menyatakan bahwa masa pemerintahan Soeharto, ia telah memperkenalkan franchising perekonomian kepada kerabat dan rekannya melalui penempatan mereka pada posisi jabatan-jabatan pemerintahan disemua lapisan.

Ringkasnya, birokrasi zaman Soeharto menggambarkan keadaan negara yang tidak stabil sehingga diperlukan peran dominan pemerintah untuk memastikan agar keadaan yang tidak stabil itu menjadi lebih baik. Warisan pemerintahan Orla yang meninggalkan banyak pekerjaan rumah bagi Soeharto dan juga pembenahan disetiap bidang kenegaraan menjadikan Soeharto untuk tegas dalam menjaga keutuhan negara, sehingga model birokrasi yang ia terapkan lebih mengarah kepada konsep birokrasi Orwell.

Konsep birokrasi Parkson dapat digambarkan melalui sistem birokrasi yang terdapat di Malaysia. Hal ini ditandai dengan meningkatnya jumlah pegawai publik, namun peningkatan jumlah pegawai bukan didorong oleh adanya penambahan kuantitas pekerjaan melainkan semakin besarnya pengaruh dari proses pembangunan ekonomi.

Pembangunan ekonomi Malaysia mengambil konsep pelaksanaan dasar perekonomian dengan membentuk "Dasar Ekonomi Baru (DEB)", dimana tujuan dari pembentukan DEB 
adalah untuk mengurangi diskriminasi pendapatan dan kekayaan antar kaum, wilayah dan kawasan dalam sebuah wilayah. Program DEB berfokus kepada penciptaan kesempatan dan peluang pekerjaan bagi rakyat.

Penciptaan kesempatan dan peluang pekerjaan dilakukan melalui pendirian pelbagai macam perusahan-perusahan negara dan badan-badan usaha negara untuk menciptakan lapangan pekerjaan yang luas bagi masyarakat lokal dengan perekonomian kelas menengah ke bawah di Malaysia. Pendirian perusahaan dan badan-badan usaha publik tersebut bersamaan dengan meningkatnya jumlah pegawai yang bekerja di sektor tersebut, hal ini kemudian telah menyebabkan peningkatan yang cukup signifikan bagi belanja negara di sektor publik.

Belanja negara yang dikeluarkan tidak hanya digunakan untuk belanja pembangunan ekonomi, namun juga dibarengi dengan beban peningkatan belanja bagi mengurus dan menggaji pegawai publik. Peningkatan belanja pegawai publik dilatarbelakangi oleh pertumbuhan lapangan kerja di sektor publik yang berusaha untuk menciptakan keadilan dan kesamarataan lapangan pekerjaan khususnya bagi masyarakat dengan ekonomi kelas menegah ke bawah.

Ahmad Atory Hussain (1998) menyatakan bahwa birokrasi di Malaysia berorientasikan pada action-oriented roles yang melibatkan empat unsur penting yaitu, pemeliharaan hukum dan peraturan, amandemen asas-asas pembangunan, pembangunan di kawasan luar kota, dan pengembangan industri. Unsur-unsur tersebut merupakan pendorong bagi tercapainya kestabilan politik teutama kestabilan ekonomi.

Sektor ekonomi merupakan solusi bagi peningkatan taraf hidup masyarakat dengan cara menyediakan lapangan pekerjaan, sehingga akan menciptakan kestabilan politik. Sektor ekonomi Malaysia sangat rentan terhadap konflik antar kaum dalam merebutkan peluang pekerjaan terutama bagi masyarakat bumiputra, oleh sebab itu kehadiran DEB berupaya untuk menjadi solusi bagi konflik yang berorientasi peluang pekerjaan antar kaum di Malaysia walaupun hal tersebut turut menyumbang peningkatan belanja sektor publik yang digunakan untuk membiayai belanja pegawai negeri.

Peningkatan jumlah pegawai negeri di Malaysia banyak terdapat di sektor pendidikan, keamanan dan kesehatan. Hal ini didasarkan kepada kebutuhan yang sangat besar akan pegawai negeri di sektor tersebut disebabkan kepada pertimbangan pentingnya ketiga-tiga sektor tersebut bagi keberlangsungan peningkatan kualitas hidup masyarakat Malaysia.

Konsep birokrasi yang terdapat di Malaysia menggambarkan bahwa bertambahnya jumlah pegawai negeri tidak berkaitan dengan bertambahnya beban kerja ataupun dapat mengurangi kuantitas beban dan waktu kerja. Berdasarkan Hukum Parkson, bertambahnya pegawai negeri akan tetap terjadi meskipun beban kerja bertambah, berkurang maupun permanen.

\section{d. Kritik Terhadap Konsep Birokrasi Orwell dan Parkson}

Implementasi konsep birokrasi Orwell pada masa pemerintahan Soeharto di Indonesia dinilai sebagai pengambilan keputusan yang sah dan tepat. Hal ini dikarenakan bahwa pada kondisi negara yang tidak stabil memang diperlukan birokrasi yang kuat untuk mendukung terlaksananya proses pembangunan negara, segala bentuk kritik, tekanan ataupun tuntutan dari individu atau kelompok dapat dianggap sebagai ancaman yang memperlambat proses pembangunan.

Dominasi pemerintahan yang kuat diperlukan untuk menjaga kestabilan negara, walaupun seringkali dominasi pemerintah ini mengarah kepada sistem pemerintahan yang bersifat otoriter. Mittleman (1996), mengambil contoh negara-negara Asia Timur seperti Taiwan, Korea Selatan dan Singapura sebagai negara yang berhasil bertahan dari segala bentuk tuntutan dan kritik yang ditujukan bagi dominasi kekuasaan di negara mereka dan menjadi negara dengan sistem ekonomi kuat.

State strong dalam konsep birokrasi Orwell diperlukan untuk mengendalikan suara rakyat sehingga tidak memunculkan tekanan dari kalangan masyarakat yang dianggap dapat 
mengganggu kestabilan negara. State strong bertujuan untuk menciptakan suatu model pembangunan ekonomi yang seringkali bertentangan dengan kehendak rakyat, sehingga menyebabkan terhambatnya proses pendemokrasian dalam sebuah negara, namun begitu state strong berupaya untuk mencapai kestabilan negara melalui kestabilan perekonomian negara yang disusul dengan munculnya stabilitas politik. Hal ini hanya dapat tercapai apabila pemerintah yang berkuasa menerapkan sistem birokrasi seperti yang diuraikan oleh Orwell.

Perkembangan konsep birokrasi Orwell tidak selalu dipandang dari sudut positif, beberapa sarjana bahkan mengkaji bahwasannya sistem birokrasi Orwell menyebabkan efek negatif terutama bagi penegakkan sistem demokrasi yang mapan. Jackson \& Pye (1978) menyatakan bahwa konsep birokrasi Orwell cenderung menyekat ruang demokrasi masyarakat banyak, birokrasi Orwell digunakan sebagai alat golongan pemerintah untuk mengendalikan masyarakat dan mempertahankan status quo, menyuburkan praktik Korupsi, Kolusi, dan Nepotisme (KKN).

Pernyataan yang diuraikan oleh Jackson \& Pye menggambarkan realita yang terjadi pada masa pemerintahan Soeharto sepanjang 32 tahun. Kontrol dan kendali yang sangat dominan dari pemerintahan Soeharto terhadap kebebasan berserikat dan kebebasan pers telah menutup ruang gerak demokrasi di Indonesia, hampir tidak ada kelompok atau golongan yang menjadi oposisi dalam pemerintahan Soeharto. Penempatan jabatan-jabatan publik yang diisi oleh kerabat dan rekan setia Soeharto serta kedekatan Soeharto dengan beberapa pengusaha yang menjadi loyalisnya telah menyuburkan praktik KKN di Indonesia.

Birokrasi Orwell menurut Jackson dapat menjamin kestabilan politik di Indonesia pada masa Soeharto dengan menciptakan program pembangunan yang dapat menggerakkan roda perekonomian pada masa tersebut sehingga pertumbuhan ekonomi berkembang pesat. Namun, penggunaan kekerasan dalam mengendalikan kritik yang muncul dari pelbagai pihak merupakan wujud dari pengekangan terhadap nilai-nilai demokrasi. Sehingga dapat dikatakan bahwa konsep birokrasi Orwell bersifat statis dalam merespon kritik rakyat tetapi responsif terhadap tekanan eksternal yang berkaitan dengan isu internasional.

Sarjana lain yang memberikan kritik terhadap konsep birokrsai Orwell ialah Gordon R. Hein (1982), ia menyatakan bahwa kekerdilan proses demokrasi terjadi apabila kendali birokrasi terhadap masyarakat dilakukan dengan cara mengakomodasi kelompok besar tanpa menganggu legitimasi rezim dan pemerintah harus mengendalikan kelompok dalam masyarakat dengan melakukan manipulasi terhadap saluran perwakilan kepentingan. Oleh karena itu, konsep birokrasi Orwell menggambarkan adanya pengekangan yang dilakukan oleh elit pemerintah sehingga menciptakan ketidakmapanan demokrasi.

Berbicara mengenai birokrasi Parkson, ada beberapa pandangan sarjana yang mendukung konsep birokrasi Pakrson yang melihat bahwa birokrasi yang besar adalah sebuah hal yang dapat diterima sebagai respon terhadap perkembangan masyarakat yang semakin kompleks dan maju. Permasalahan yang seringkali terjadi pada negara-negara dengan jumlah penduduk yang besar ialah keterbatasan lapangan kerja, sehingga untuk memenuhi kebutuhan akan lapangan pekerjaan maka program pembukaan lapangan pekerjaan oleh negara harus dilakukan hal ini juga harus dibarengi dengan peningkatan jumlah pegawai publik.

Esman (1972) menyatakan bahwa administrasi pembangunan pada dasarnya melihat peran administrasi pemerintah dalam mendorong, mengarahkan dan mengurus proses yang saling berkaitan dengan pembangunan negara (nation building), pertumbuhan ekonomi dan perubahan sosial. Oleh karena itu, program pembangunan yang direncanakan oleh pemerintah harus berpedoman kepada sistem pengelolaan administrasi pemerintah, dalam artian harus diikuti oleh sumber daya manusia yang memadai untuk melaksanakan program tersebut. Hal ini tidak terlepas dari konsep pembangunan sebuah negara selalu diikuti dengan pelbagai pertumbuhan disegala sektor terutama ekonomi, dan yang menjalankan pengurusan dan manajemen pada sektor-sektor administrasi tersebut adalah pegawai publik. 
Maizatul Haizan (2002) menyatakan bahwa konsep administrasi yang diutarakan oleh Esman memberi tumpuan kepada dua aspek utama yaitu membangun institusi administrasi dan berupaya agar dapat memperbaiki manajemen dalam menangani proses perubahan dan membentuk serta melaksanakan program pembangunan dalam semua aspek kebijakan publik. Dua konsep yang Esman kemukakan diatas tergambar dalam implementasi birokrasi yang dilaksanakan oleh pemerintah Malaysia, dimana pemerintahan Malaysia berperan penting dalam memenuhi perubahan yang terjadi melalui proses pembangunan negara melalui pendirian badan-badan maupun institusi milik negara.

Evers (1987) dalam kajiannya di wilayah Asia Tenggara, Evers mengemukakan sebuah kajian rasional mengenai rasio penduduk terhadap jumlah pegawai sebagai kritik terhadap birokrasi Parkson. Nilai rasio pegawai-penduduk dianalogikan sebagai sama dengan nilai inflasi mata uang dalam konteks keefesienan, maka apabila sebuah negara mengimplementasikan birokrasi Parkson maka akan semakin tinggi juga beban birokrasi terhadap keuangan sebuah negara.

Besarnya beban keuangan yang harus dikeluarkan oleh pemerintah Malaysia terhadap pegawai publik di Malaysia, mendorong pemerintah untuk mencari alternatif baru bagi pemecahan permasalahan birokrasi tanpa menghilangkan lapangan pekerjaan bagi masyarakatnya, terutama bagi penduduk bumiputra. Kritik terhadap birokrasi Parkson kemudian memunculkan pilihan dalam membentuk sebuah sistem reformasi di tubuh birokrasi, hal ini dilakukan untuk mewujudkan sistem birokrasi yang efektif dan efisien.

David Osborne \& Ted Gaebler (1992) memandang perlunya alternatif baru terhadap sistem dan organisasi di sektor publik dengan mengusulkan sebuah paradigma baru terhadap struktur birokrasi yang menggabungkan nilai-nilai utama sektor perdagangan dan perusahaan ke dalam administrasi publik. Hal ini kemudian di adaptasi oleh pemerintahan Malaysia di bawah kepemimpinan Tun Dr. Mahatir Mohamad dengan mereformasi sektor publik yang tidak aktif, produktif dan berdaya saing.

Konsep birokrasi Parkson pada akhirnya berkembang kepada dua pandangan yang berbeda, pertama keperluan terhadap birokrasi yang besar sebagai respon kepada bertambahnya peran birokrasi yang akomodatif terhadap tuntutan lingkungan dan masyarakat, dan kedua tuntutan terhadap reformasi birokrasi melalui penerapan New Public Management (NPM) sebagai respon terhadap implementasi birokrasi yang kurang efektif dan efisien dalam menjawab tantangan globalisasi.

\section{SIMPULAN}

Konsep birokrasi Orwell dan Parkson merupakan dua konsep yang tepat untuk mengkaji mengenai sistem birokrasi yang terdapat di Indonesia pada masa Soeharto dan di Malaysia pada masa kepemimpinan Tun Mahatir. Meskipun setiap konsep memiliki kelemahan, namun apabila mampu diaplikasikan sesuai dengan program yang telah tersusun maka akan menciptakan sebuah ruang administrasi yang mapan, bahkan mampu mengantarkan keberhasilan kepada kemajuan sebuah negara. Hal ini jelas terlihat dari pengalaman Taiwan, Korea Selatan dan Singapura.

Melalui konsep birokrasi Orwell, dominasi yang kuat oleh pemerintah dapat menciptakan kestabilan politik pada sebuah negara, seperti halnya di Indoensia pada zaman pemerintahan Soeharto atau dikenal dengan rezim Orde Baru. Namun begitu, konsep birokrasi ini banyak meninggalkan kecacatan pada sektor lainnya, seperti tidak adanya penghargaan terhadap Hak Asasi Manusia, sistem pemerintahan yang cenderung bersifat Otoriter serta meluasnya praktik KKN.

Konsep sistem birokrasi Parkson memberikan dorongan bagi terciptanya pemenuhan terhadap kebutuhan pembangunan negara. Namun, perekrutan yang tidak dibarengi dengan analisa matang tidak akan mampu mengimbangi belanja pemerintah dalam hal pemenuhan hak- 
hak pegawai publik. Merujuk kepada sistem birokrasi Parkson yang dianut oleh Malaysia, menggambarkan bahwa sebagian besar pegawai pemerintahan tidak menjalankan tugas sesuai dengan fungsinya, hal ini menyebabkan kurang produktifnya pegawai publik namun menyerap banyak biaya untuk membayar gaji pegawai.

\section{REFERENSI}

Goerge Orwell. 1949. 1984 (Nineteen Eighty-Four). United Kingdom: Secker \& Warburg.

C. Northcote Parkinson. 1957. Parkinson's Law. USA: The Riverside Press.

Etzioni, A. (1964). Modern Organization. United States: Prentice-Hall, Inc.

Liddle, R.W. 1985. Soeharto's Indonesia: Personal Rule and Political Institutions.Pacific Affairs. Vol 58(1): 68-90.

Syamsuddin Haris. 2014. Partai Pemilu, dan Parlemen Era Reformasi. Jakarta: Yayasan Pustaka Obor Indonesia.

Crouch, H. 1979. Patrimonialism and Military Rule in Indonesia. World Politics. Vol 31(4):571-587.

Ahmad Atory Hussain. 1998. Reformasi pentadbiran di Malaysia. Kuala Lumpur: Utusan Publication \& Distributions. . 1990. Pentadbiran awam: asas pemikiran dan falsafah. Kuala Lumpur: DBP. 2001. Pengantar pentadbiran awam: paradigma baru. Kuala Lumpur: Utusan Publications \& Distributors.

James H. Mittelman. 1996. Globalization: critical reflection. Lynne Rienner Publisher.

Karl Jackson \& Lucian Pye. 1978. Political Power and Communications in Indonesia. Berkeley, Calif: University of California Press.

Gordon R. Hein. 1982. Electoral Victory and Economic Adjustment for the New Order. Asian Survey. Vol. 23, No. 2, A Survey of Asia in 1982: Part II (Feb, 1983), pp. 178-190.

M.J. Esman. 1972. The Elements of Institution Building. In J. Eaton (ed). Institution Building and Development. Baverly Hills, CA: Sage.

Maizatul Haizan Mahbob. 2002. Pembangunan institusi dan pentadbiran di Malaysia.

Dalam Politik Malaysia: perspektif teori dan praktik, disunting oleh Ghazali Mayudin. Bangi: UKM.

Evers, H. D. 1987. The bureaucratization of Southeast Asia. Comparative Studies in Society and History 29 (4), 666-685.

David Osborne \& Ted Gaebler. 1992. Reinventing Government. Addison-Wesley.

Saefullah Fatah. 1998. Catatan atas gagalnya politik Orde Baru. Yogyakarta: Pustaka Pelajar.

Parkinson, C.N. 1955. Parkinson's Law. The Economist. http://www.economist.com/node/14116 121 [20 Mei 2014].

Priyo Budi Santoso. 1993. Birokrasi Pemerintah Orde Baru: Perspektif Kultural dan Struktural. Jakarta: PT Rajagrafindo Persada.

Scott, W. R. (2003). Organizations: Rational, Natural, and Open Systems. (5th ed). New Jersey: Pearson Education, Inc.

Siti Alida John Abdullah \& Halimah Ahmad. 2001. Penilaian Saiz Sektor Awam diMalaysia Semenjak Dasar Ekonomi Baru dan Perbandingan Dengan Beberapa Buah Negara. Sintok: Sintok Sekolah Pembangunan Sosial, Universiti Utara Malaysia.

Zuriana Zahrin \& Aznida Shahidan. 2007. Perkembangan Saiz Sektor Awam di Malaysia: Perspektif teori dan Realiti. Dalam Isu-isu Kontemporari Pengurusan Awam. Petaling Jaya: Prentice Hall 